\title{
INDUSTRIAL BETTERMENT ACTIVITIES OF THE NATIONAL METAL TRADES ASSOCIATION
}

\author{
By ROBERT Wuest, \\ Cleveland, Ohio.
}

The National Metal Trades Association is an organization of national scope, composed of manufacturers of metal products who employ machinists, millwrights, boiler-makers, pattern-makers, coppersmiths, polishers and buffers. The very keynote of the principles for which the association stands is found in article 1 of its constitution, viz:

(1) "To secure and preserve equitable conditions in the workshops of members for the protection of both employer and employee.

(2) "Investigation and adjustment of questions arising between members and their employees which may come within the jurisdiction of the association."

\section{History}

In order better to understand the present position of the association, we will review briefly its history and progress and try to show to the reader the fact that its organizers "builded better than they knew" when they launched the movement which resulted in the association as it is found to-day. The association was organized on August 21, 1899.

The newly-formed association's policy being one of conciliation and adjustment, a board of conciliation composed of members of the association and of officers of the International Association of Machinists was formed, who entered into an agreement which was signed by both organizations on March 31, 1900. On May 18, 1900, this board of conciliation met in New York City and adopted a working agreement, in many respects the best ever made between employers and employees.

Industrial peace, as far as members of both organizations were concerned, seemed assured and while disputes necessarily arose, they were settled by the board of conciliation. In the spring of 1901 came the first rupture, when the International Association of Machinists 
presented certain demands and refused to confer with the conciliation committee of the National Metal Trades Association, but on May 20, 1901, called a country-wide strike to enforce its demands. This resulted in the formal abrogation by the National Metal Trades Association of the so-called New York agreement on June 10,1901 , at a special meeting called to consider the situation, and the adoption on June 18, 1901, of the present "Declaration of Principles" under which the organization is now working. While we can only speculate as to what might have been the results of continued bargaining between the two associations, we are justified, by the sequence of events in the history of labor organizations and particularly those with which the National Metal Trades Association has had to deal, in believing that it was providential that the break came when it did, as concessions on the part of the employers, but led to further demands with the one object in view, by the officers of the labor unions, to dominate the industrial situation and dictate terms upon which manufacturers should be permitted to do business.

Deploring the necessity of combating strikes, but impelled by the law of self-preservation to do so, the association took up the work of manning the shops of its members and getting business back to its normal channels on the basis of the open shop and opportunity for all. This was accomplished in due time and then the association entered upon "a program of constructive work which is steadily growing larger and increasing in importance, looking to industrial betterment not only in the shops of its members, but throughout the whole length and breadth of the land.

The members of the National Metal Trades Association are for the most part men of ability, students of affairs, political, social and economic, men of broad sympathies and humane instincts who are helping to awaken what has been called "the public conscience," and a dominant note in the declaration of principles of the association is contained in the words taken therefrom which follow: "This association will not countenance any conditions of wages which are not just, or which will not allow a workman of average efficiency to earn at least a fair wage."

\section{Constructive Activities}

The association holds an annual convention at which the business of the old year is reviewed, and the plans laid for the coming 
year's work. The officers and administrative council are elected and the various committees appointed. The administrative council, which meets twice yearly, is clothed with plenary powers to act for the association on all matters needing attention in the interim between conventions, and acts in its turn through an executive committee between its sessions.

Papers are read and discussions held at the annual meetings on subjects of importance and interest to members, resulting in an exchange of ideas and a dissemination of knowledge which is of great value to the trade in general. The social side of life is not neglected at these gatherings and many pleasant and lasting friendships are thereby formed amongst men who, under the old order of things, would conjure up pictures of each other as the personification of all that is diabolical. Certainly this is one of the many changes for the better, growing out of the modern idea of cooperation and association with one's fellows and co-laborers in the same general field.

Among the subjects with which the association has concerned itself and upon which it has spent much time and energy are: Industrial education and the training of apprentices; legislation in the states and in congress; cooperative profit-sharing plans; the publication of a periodical, first under the name of The Open Shop, and later in conjunction with the National Founders' Association under the name of The Review, for the purpose of placing before workmen subjects which are mutually advantageous to employer and employee; the fostering of the movement for greater safety, better hygienic and sanitary surroundings in shop and factory; the establishment of local employment bureaus the better to provide suitable workmen for employers and positions to fit the capabilities of employees.

\section{Industrial Education and Apprentices}

The National Metal Trades Association has always realized that the question of industrial education for boys is a serious one, and that it will grow in importance with the flight of time. One of the early efforts in this line was made through a committee of the association in connection with equipping with machinery certain buildings in the Winona Technical Institute of Indianapolis, Ind., and the furnishing of scholarships of the value of $\$ 100$ each for prospective students. The committee did very effective work in soliciting the contributions of equipment and scholarships which were made by individual 
members of the association to the institute. Later the association in conjunction with Indianapolis members voted financial support to the institute for the maintenance of a metal trades department, and appointed a committee to cooperate with the officers of the institution in the management of that department.

In cooperation with the University of Cincinnati under Professor Herman Schneider, members of the National Metal Trades Association opened their shops of 1906 to the students in the university's Cooperative Course in Engineering, with the result that young men are now getting a practical and technical training which was impossible under the old order of things. That this movement is filling a long-felt want may best be judged by the reported facts that the products of this course are eagerly sought after and are being absorbed by the trade faster, in some cases, than the finishing processes are completed, and that the number of applicants for enrolment is reported many times greater than the facilities available at the university will accommodate.

It is interesting to note that the manufacturer in the metal trades is always glad to secure the services of a German machinist because of his better technical and theoretical training. The only drawback to this type, as voiced by one employer, being that after a while they seem to appreciate their superiority over the other workmen and develop a more or less annoying case of self-importance. When it is pointed out that these men are the fruit of a system which we in America are trying to inaugurate, the employer who has one of them readily sees the point and is more than ever willing to help along this type of education. The complaint has been made that the graduates of some of the higher grades of educational institutions are a little afraid of soiling their hands and clothes, or of donning a suit of overalls, indicating the advisability of extending the field of the purely trade school and providing industrial training and education for the boy who, for reasons wholly beyond his own or his parents' control, is obliged to fare forth and assist in providing the necessaries of life for the family. The need for education on the part of such boys has been provided for in some instances by the organization on the part of members of the National Metal Trades Association of apprentice schools in the plant or factory of the member. Arrangements are made for a teacher and the boys are alternated in small groups between the school room and the shop. In 
one instance in Cleveland, where the demand was great and no one manufacturer would undertake such a work alone, the Young Men's Christian Association was induced to take up the work of organizing and teaching, while the manufacturers, members of the National Metal Trades Association, and others, furnished scholarships of a certain value, and agreed to allow the boys opportunity in the day time to attend the classes on certain days each week. The great avidity with which boys grasped the opportunities is the most eloquent testimonial to the merits of this plan.

The great economic, social and industrial gain by the continuance of these measures can hardly be estimated. We are thereby producing better mechanics, better workmen, better citizens and better men in every conceivable respect than if this same material had been allowed to drift into the unskilled occupations, or to grow up on the street. The National Metal Trades Association by its active interest and work in this field has no doubt been the means of awakening the interest of the individual members, and thereby spreading the movement farther and farther.

Realizing, after some time, that the spread of industrial education should be in the hands of specialists, and knowing of the work of the National Association for the Promotion of Industrial Education to this end, the National Metal Trades Association, at its annual convention in 1911, appropriated money to be used in the discretion of its administrative council for advancing the work undertaken by the former. Of this amount a part was paid over to the National Association for the Promotion of Industrial Education in the autumn of 1911 and the disposition of the balance was left with the administrative council by the convention of 1912 .

The National Metal Trades Association has identified itself with this movement, both as a national body and through its branches, and in addition to the instances above noted, members of the National Metal Trades Association in branch territory have lent their support to institutions which are teaching students along industrial lines. In Chicago, the Lewis Institute receives the cooperation of the association; Cincinnati's Continuation School and Cooperative High School, in addition to the university there, are training mechanics in many trades and have the members' hearty approval; Cleveland has its technical high school in the public school system in addition to the work being done by the Young Men's Christian Association 
above mentioned; members in Hartford, Conn., have induced the public school authorities there to inaugurate a continuation school to which they will send their apprentices; New Haven, Conn., members have cooperated with the Boardman School there, and are trying to induce the board of education to take up the matter of industrial training for the apprentices in their shops; St. Louis, Mo., members are working with the Rankin Trade School in that city and report very gratifying progress; in fact, wherever members of the National Metal Trades Association are found, they are alive to the necessity of education for the American boy of a sort to fit him for his life work, thus increasing our national industrial efficiency and enabling our country to hold its own in the markets of the world with those nations who long since saw the advantages of the system we are trying to upbuild, and who are and have for some time been reaping the golden harvest from their wisdom and foresight. Welltrained apprentices are already going from the shops and factories of members of the National Metal Trades Association to the ranks of the mechanics of the country, making for industrial betterment of the whole nation as a result of the efforts of the association to spread the new gospel of industrial education.

In the course of his training under the new system, the apprentice will acquire a fair knowledge of economics and will be better able to appreciate the fact that his employer has problems which perplex him and that he is not a "machine for raising wages," to borrow an expression from one of our members.

This will tend to make for industrial peace, as from his broader mental horizon the mechanic will be able to appreciate some of the difficulties of the manufacturer and this will cause him to temper with reason his demands upon his employer.

\section{Cooperative Profit-Sharing Plans}

The National Metal Trades Association has always advocated the payment by its members of the highest rate of wages possible in the locality in which the manufacturer finds himself. Wages being a purely local question, the fixing of rates of wages is left to the localities affected and is a matter in which the association takes no part.

Profit-sharing plans have been discussed at annual conventions of the association and are in use amongst the members. 
One of these is Crane Company's well known plan of an annual distribution amongst their employees of a certain percentage of the earnings of each man for the past year. The payment is made about Christmas time and is known as a "Christmas present." A man discharged for cause, or leaving of his own accord, forfeits his share, while one who is away without fault is entitled to participate pro rata. Another plan contemplates first, the payment of a given dividend on the investment of the manufacturer out of the profits, and of what remains an agreed division is made between the company and its employees. Other plans are based on the purchase by the employee of stock in the employing company to be paid for by instalments out of dividends or wages.

The payment of a bonus, or a premium, as distinguished from the old piece-work system, for work done over and above an agreed amount, gives the workmen of exceptional ability an incentive to increase his earnings by steady and consistent work, and this plan is in use in a great many members' shops and factories. It leads to suggestions for shortening the time in which operations can be done and for improvement in equipment.

A plan of paying to the workmen a reward for inventions which are patentable and improvements which are valuable, although not patentable, encourages employees to use their brains for industrial betterment, and is in use in some members' plants.

We believe that a profit-sharing plan put in operation tends to decrease the possibility of industrial disturbance, encourages thrift on the part of employees and gives them an interest in the operation of the plant which is otherwise wanting.

Mr. N. O. Nelson, of the N. O. Nelson Manufacturing Company, of St. Louis, Mo., expressed it well when he said: "Profitsharing is a peace measure but it is not a guarantee against strikes. There can still be differences, but they will be rare. There are still the class influences but they are weakened. For these reasons. profit-sharing is not favorably regarded by union leaders."

\section{Safety Appliances, Hygiene and Sanitation}

The National Metal Trades Association has consistently taken the position that the first step in the plan of compensation for industrial accidents is the prevention of accidents. The question of greater safety in the shops of the members has been discussed at each annual convention for years, and the association has tried in many ways to 
interest its individual members in reducing to a minimum the number of mishaps in their plants. In furtherance of this plan a man who has made the matter a subject of considerable study, being a mechanic of great ability, was appointed safety inspector of the association, and was given the task of inspecting the shops of members, with a view to pointing out to those in charge the danger spots of the plants, and to suggest the remedy to be applied. The employers were a unit in the cordial reception of the plan, and many letters were received asking that the inspector be hurried along as soon as possible. The officials of the plants that were well protected seemed equally anxious with those who theretofore had perhaps given the matter only casual thought to receive suggestions to increase the safety of their equipment. Singularly enough, the employees who were to be directly benefited were ofttimes the reverse of enthusiastic over the necessary changes, and a campaign of education on the subject became necessary. A safety device was often looked upon as a reflection on the workman's skill. Lectures and talks, illustrated by lantern slides, have been and are being given by the association's safety inspector to groups of workmen and employers, to classes of students and apprentices, and wherever interest in the subject has been displayed. The association makes no charge for these lectures beyond the necessary traveling expenses of the inspector. If the inspector happens to be in the neighborhood of the proposed gathering there is no expense in connection therewith.

Another step in advancing the safety idea was taken by the association when it published a pamphlet on "Safety Appliances." The object was to place before members and others interested a convenient list of devices for the prevention of industrial accidents.

The subjects of hygienic and sanitary surroundings for employees have been discussed and constantly called to the attention of members, as there can be no doubt that a pleasant place in which to work adds to the efficiency of the workman, although employers in this day are humane enough to provide these things on other than a sordid basis.

That the efforts of the association in this field have resulted in improved conditions throughout the trade, and will continue to produce results far beyond the cost of the work, cannot be doubted. The ultimate saving in dollars and cents whether under employers' liability and compensation acts or under the casualty insurance policy plan should be considerable. This is, in our opinion, one of the most important activities of the association for industrial 
betterment and tends to cut to the irreducible minimum the list of casualties in the industry.

\section{Systematic Compensation for Industrial Accidents}

A subject which is closely allied to that of safety is compensation to the victims of industrial accidents. The enormous toll of life and limb which has been taken by the industrial world in the past is simply appalling, and the National Metal Trades Association early in its history took steps to reduce it to the minimum beyond which accidents seem to be inevitable, and for these it early took the position that the old common law basis of fault as a ground for recovery or defense, as the case might be, was ill-suited to the conditions of our times. This common law doctrine grew up when individual effort and undertaking were largely the order of the day and vast aggregations of capital and the use of machinery by considerable number of workmen were things unknown. It was early recognized that the burden of inevitable accidents should be carried, not wholly by the victim and his dependents, but in part, at least, by the industry responsible for them so that the cost could be in turn charged to the consumer. When this subject was first broached in the annual conventions of the association, its members, like all other employers, were somewhat in the dark as to what plan to pursue, but a committee was appointed and has been continuously kept at work to keep the members informed, and to work for uniform provisions throughout the country. The movement gathered headway very rapidly until to-day a large number of the states have legislated for a systematic compensation for industrial accidents and the congress of the United States has before it a bill applicable to the railroads of the country doing an interstate business.

We believe that this tendency to place the burden where it belongs is a great step in industrial betterment, that it will tend tc maintain peace in industrial pursuits, and eliminate the feelings of hostility and hatred engendered by the old system of the damage suit based on negligence.

\section{Legislation}

The National Metal Trades Association at all times takes a lively interest in legislative matters. It has worked for the enactment of laws having for their object the better protection and development of American manufactures, and it has opposed legis- 
lation which was thought to be inimical to the best interests of the nation as a whole, recognizing the fact that legislation which will injure the workman will also injure the employer, and vice versa. The association has never acted in any way as an obstructionist, but has freely lent its help and influence to the passage of useful legislation whenever possible. A recent instance of this was the resolution passed at its annual convention endorsing the so-called "Page bill," which seeks to provide federal aid for the furtherance of education in industrial and household arts and agricultural training for the young people of the nation. At the time when frequent dynamite outrages were attracting the attention of the country, the association took action upon the subject at one of its annual conventions by instructing its administrative council to investigate the question of a regulation of the manufacture and sale of high explosives. This resulted in the drafting of a bill as a basis for legislation in the states, which it is thought would serve to make it very difficult, if not impossible, for law-breakers to obtain explosives unless they stole them, but would not interfere with the possession for a legal purpose of any quantity of the substance. Many other specific instances of the interest of the association in such matters could be cited. Intelligent interest in the pending legislation by the citizen is always desirable, and such interest by members of an organization in subjects peculiarly within its field of operations can but make, we believe, for industrial improvement and betterment generally.

\section{Extension of Transportation Facilities}

The National Metal Trades Association has gone on record at its annual conventions as favoring intelligent extension with some of the old-time vigor and courage exhibited in planning for expected future traffic demand of railroad facilities in place of the ultra-conservative attitude exhibited lately by the common carriers of the country. This shows a realization that transportation facilities make for industrial progress and betterment both in the locality served and the country at large.

\section{"The Review"}

In order to help the workmen to understand better the economic problems which confront the country, the National Metal Trades 
Association, in conjunction with the National Founders' Association, publishes a monthly magazine known as The Review. This magazine addresses itself to live questions which will interest men who work in foundries, factories and machine shops, and disseminates information as to the trades in question which serves to educate the workmen. The man who has some knowledge of such questions is better able to appreciate the fact the employers must produce wealth before it can be disbursed, and that the employment of capital as well as labor is necessary in any industrial enterprise. The Review is sent on request to anyone sufficiently interested to write for copies, or ask that their name be entered upon the mailing list. Large numbers of workmen in foundries, factories and machine shops take advantage of this fact, and the material laid before them is usually of a high order. This can but reduce the tendency to industrial war, for if a man is acquainted with both sides of a situation he is less likely to rush into strife than if he has but his own point of view.

\section{Local Branches and Employment Bureaus}

In the constitution of the National Metal Trades Association a system of local branches is provided for, each with its set of officers, including a paid secretary who has charge of the active work of the branch. In connection with each branch an employment bureau is maintained which serves as a clearing house for the members of the association in branch territory from which to procure their labor supply. The operation of the bureau is not confined to the so-called trades, but men who are seeking executive and other positions in connection with the metal trades are encouraged to make use of the bureau to obtain them. No discrimination is made against workmen whether affiliated with unions or not, the sole requirement being that, if a union man, he must agree to work peaceably side by side with his fellow workman without reference to the question of his being union or non-union. The bureau serves as a place to which a man may report his unemployment as soon as he is out of work. The results of the workings of these bureaus have been that a minimum of effort has been expended on the part of the employer and employee in coming together, and a very high class of workmen has been procured for the shops of members, while employees are encouraged to look for promotion through the bureaus as well as in the shops. 
This, we think, is one of the greatest activities of the association which tend to industrial peace and betterment.

\section{Conclusion}

In reviewing the history of the association and looking into the future, we are well justified in believing with the president of our association for 1911, Mr. F. C. Caldwell, that "the problems which we, as an association, have been endeavoring to solve are just as serious and just as important to the welfare of the country as any of the political problems that are now engaging our attention. If we are right in our contentions, and we are certainly sincere in believing that we are right, our efforts in endeavoring to maintain the principles of this association are just as patriotic and just as beneficial to the welfare not only of our industry but also the country at large, as the benefits that accrue from the right settlement of any great public question." 